\title{
VARIOUS EVALUATION IN PHYSICS AND MATHEMATICS FACULTIES OF GENERAL EDUCATIONAL SCIENCES
}

\author{
Mirzaaxmad Qurbonov \\ National University of Uzbekistan, Doctor of Pedagogical Sciences, Professor
}

\author{
Oxista Dehqonova \\ Fergana State University, Teacher
}

\begin{abstract}
ANNOTATION
The article analyzes the integration of physics and mathematics in general secondary schools.

KEY WORDS: continuity, optimized curriculum, quadratic equation, coordinate line, thermometer, surface, pressure, volume, density, parabola, exponential function, logarithmic function, modular function.
\end{abstract}

As you know, the development of physics is closely related to the development of mathematics and technology. Mathematical apparatus is widely used to study of physical phenomena and de termine the laws of action. As far as mathematical intelligence is concerned, the development of a set of tracks can be enhanced with the help of the fits.

The following is a summary of topics in physics and mathematics in secondary schools.

In the mathematical-optimized curriculum, the subject of fractions has been expanded from 6th to 5th grades. The problem is that the trunk should have an unknown square. Finding an unknown number of equations in primary classes is the solution of quadratic equations in the 8th class mathematical course. Coordinate line, where placement of numbers, and the idea of negative numbers give students the opportunity to learn the structure and performance of the thermometer. The concept of the surface in mathematics allows the concept of pressure in physics, and the concept of volume enables the concept of density in physics. In elementary grades, pupils have become accustomed to solving specific issues. The solution to some physics problems is relative. Many teachers of mathematics and physics need to be trained to carry out approximate calculations in solving some of the examples. It is also necessary to explain in physics that some measurements are approximate and that the approximate quantity of the associated value is approximate.

Typically, distance, surface, size, angular size is referred to as mathematical magnitudes. In mathematics, the properties of these magnitudes and the theory of their measurement have been developed.

Pupils do a lot of measuring works in experiments. Before doing this, they are practicing mathematics, they eliminate issues related to length, surface, volume, mass, velocity measurement, and some of these skills, because they are directly measured in mathematics. Mathematical knowledge also helps to formulate concepts such as accuracy of measurements of measuring devices.

One of the most important forms of interaction between physics and mathematics is solving mathematical problems in physics. At the same time, it is helpful to solve physical and mathematical problems (fluency and intensity). Physics science mathematics arithmetic or. Not only because of algebraic expressions, but also with geometry. The shape of the objects is a square, square, circle, triangle, polygon, sphere, cube, 


\section{International Journal of} Asian Economic Light (JAEL) - Peer Reviewed Journal

SJIF Impact Factor (2021): 7.32

parallelepiped with right angle, etc. may be in the multiplication. In doing so, their size is determined by the use of knowledge gained in geometry.

\section{The Continuity of Physics and Mathematics Knowledge in General Secondary Schools}

Table 1

\begin{tabular}{|c|c|}
\hline Advantages & Note \\
\hline $\begin{array}{c}\text { Interest will be required to start the Physics } \\
\text { course in percentages }\end{array}$ & In the 5th grade maths textbook \\
\hline $\begin{array}{c}\text { The concept of proportional ratio in the physics } \\
\text { class is very important }\end{array}$ & $\begin{array}{c}\text { In Grade 5 proportion, inverse proportion, and } \\
\text { proportions. }\end{array}$ \\
\hline The 5th grade maths textbook should be used & $\begin{array}{c}\text { In the 7th Grade Physics textbook, given the } \\
\text { background and size of the Archimedes }\end{array}$ \\
\hline $\begin{array}{c}\text { The 7th Grade Physics textbook gives } \\
\text { information about speed velocity expression vectors }\end{array}$ & In the 7th Grade Geometry \\
\hline $\begin{array}{c}\text { The 7th grade algebra textbook includes the } \\
\text { subject of "combinatorial elements" which, in its turn }\end{array}$ & $\begin{array}{c}\text { Can be used to solve the question of "how } \\
\text { many different types of resistance can be combined?" }\end{array}$ \\
\hline $\begin{array}{c}\text { Mathematics lesson is 5-6 hours per week. It is } \\
\text { as much as possible and deeper into science, which } \\
\text { allows for consolidation. }\end{array}$ & $\begin{array}{c}\text { This increases the accuracy of calculations in } \\
\text { Physics, and can not be difficult to understand. }\end{array}$ \\
\hline
\end{tabular}

Table 2

\begin{tabular}{|c|c|}
\hline Disadvantages & Note \\
\hline $\begin{array}{l}\text { Don't standardized form of number and } \\
\text { apporoximate calculations. }\end{array}$ & $\begin{array}{l}\text { The standard form of the subject is given in the } \\
\text { 8th class algebra textbook. }\end{array}$ \\
\hline $\begin{array}{l}\text { In the } 7 \text { th grade textbooks, the theme of the } \\
\text { forces or the speeds, when opened with square rows in } \\
\text { the path of the invaded, opens "module." }\end{array}$ & $\begin{array}{l}\text { The theme of the module is presented in the } 8 \text { th } \\
\text { grade algebra }\end{array}$ \\
\hline $\begin{array}{l}\text { Failure to Complete the Movement in the 7th } \\
\text { Grade Course }\end{array}$ & $\begin{array}{l}\text { "The Distance Between Two Points" in the 8th } \\
\text { Grade Geometry Tutorial }\end{array}$ \\
\hline $\begin{array}{l}\text { The 7th Grade Physics textbook has the subject } \\
\text { "Friction Force". Trigonometry for the expression of } \\
\text { frictional force in the plane plane Trigonometry is }\end{array}$ & In the 9th class geometry and algebra textbooks \\
\hline $\begin{array}{l}\text { The absence of Theorem theorem on the "final } \\
\text { velocity" or "relative velocity" in the } 7 \text { th grade } \\
\text { Physics textbook is given in the Cosinus }\end{array}$ & $\begin{array}{l}\text { "Law of Cosines" is given in } 9 \text { th grade } \\
\text { Geometry textbook. }\end{array}$ \\
\hline $\begin{array}{l}\text { Do not know if } \mathrm{h}=\mathrm{gt}^{2} / 2 \mathrm{~h}=\mathrm{h}\left(\mathrm{t}^{2}\right) \text { is a } \\
\text { parabola in the theme "Effects on the power of mind" } \\
\text { in the } 7 \text { th grade Physics textbook. }\end{array}$ & $\begin{array}{l}\text { The theme of "Square Function" is in the 8th } \\
\text { class algebra textbook }\end{array}$ \\
\hline $\begin{array}{l}\text { In the physics textbook of the } 7 \text { th grade it is } \\
\text { impossible to add vectors or use the Pythagoras to add } \\
\text { or multiply the forces }\end{array}$ & $\begin{array}{l}\text { The angle of the triangle, the theme of the } \\
\text { pitapor in the 8th class geometry textbook }\end{array}$ \\
\hline $\begin{array}{l}\text { The 7th grade textbook gives examples of } \\
\text { quadratic equations in the subject of quizzes. }\end{array}$ & $\begin{array}{l}\text { The theme of Quadratic Equation is the 8th } \\
\text { class algebra textbook. }\end{array}$ \\
\hline $\begin{array}{l}\text { The topic "Logarithmic Equations and } \\
\text { Inequalities", which gives a logarithmic equation in } \\
\text { the formula } N=N_{0} * 2^{\frac{-t}{T}} \mathrm{t} \text { on the subject of } \\
\text { "degradation" In the 9th class atom and core is }\end{array}$ & In the 10th class algebra \\
\hline $\begin{array}{l}\text { The 9th Grade Physics textbook gives the } \\
\text { Elementary Functions The theme of "Elementary } \\
\text { Functions" }\end{array}$ & $\begin{array}{l}\text { The 10th Grade Physics textbook gives the } \\
\text { integral representation of the subject on the subject } \\
\text { of"power of the day". }\end{array}$ \\
\hline
\end{tabular}




\section{Implementation of mathematical formulas in physics}

Table 3

\begin{tabular}{|c|c|}
\hline $\begin{array}{l}\text { Linear function - } y=k x \\
\begin{array}{l}S=v t \\
F=m g \\
F=k x \\
M=F l \\
F=I \mathrm{~B} \operatorname{lsin} \varphi\end{array}\end{array}$ & $\begin{array}{l}\text { Square function }-y=a x^{2} \\
\qquad \begin{array}{c}E=\frac{m v^{2}}{2} \\
W=\frac{k x^{2}}{2} \\
F=-k v^{2}\end{array}\end{array}$ \\
\hline $\begin{array}{l}\text { Hyberbolic function }-y=\frac{k}{x} \\
\begin{array}{l}W=-\frac{G m_{1} \mathrm{~m}_{2}}{r} \\
W=k \frac{q_{1} \mathrm{q}_{2}}{r} \\
a=\frac{F}{m} \\
a_{n}=\frac{v^{2}}{R}\end{array}\end{array}$ & $\begin{array}{l}y=\frac{k}{x^{2}}-- \text { function } \\
F=\frac{G m_{1} \mathrm{~m}_{2}}{r^{2}} \\
F=\frac{k q_{1} q_{2}}{r^{2}}\end{array}$ \\
\hline$y=k \sqrt{x}$ function & $\begin{array}{c}\text { Indicative function } y=a^{x} \\
N=N_{\mathrm{o}} 2^{-\frac{t}{T}} \\
I=I_{\mathrm{o}} \mathrm{e}^{-a x}\end{array}$ \\
\hline $\begin{array}{c}\text { Modular function } y=k|x| \\
\qquad F=k \frac{\left|q_{1}\right|\left|q_{2}\right|}{r^{2}}\end{array}$ & $\begin{array}{l}\text { Logarithmic function- } y=\log _{a} x \\
\qquad \theta=\ln \frac{x_{1}}{x_{2}}\end{array}$ \\
\hline
\end{tabular}

As an example, we analyze the above tables:

1) The fact that a phyusics textbook is inextricably linked with mathematics can be seen in the example of a e triginometric function.

In the 7 th grade physics textbook on Newton's 2 nd law, we know that the acceleration of a body of constant mass is directly proportional to the force and the acceleration of the body under constant force is inversely proportional to the mass, i.e. $\mathrm{a}=\frac{F}{m}$

2) We often need math when solving physics problems. In addition to the functions listed above, we often encounter parabolic functions. 


\section{International Journal of Asian Economic Light (JAEL) - Peer Reviewed Journal Volume: 9 | Issue: 1 | February 2021}

SJIF Impact Factor (2021): 7.32

This is very useful in the mechanics department of physics on the subject of the motion of a body under the influence of gravity. We can also see in the law of conservation of energy: $h=g \frac{t^{2}}{2} \quad E=\frac{m v^{2}}{2}$ $S=\frac{a \cdot t^{2}}{2} \quad W=k \cdot \frac{x^{2}}{2}$

to understand a parabolic function, one must first know the graph, the domain of detection, the domain of values, and its properties. If the student knows and solves the following by applying it to Physics, it will be expedient.

All of the above are listed in the 8th grade Algebra textbook.

In summary, prior to teaching physics, mathematical knowledge included logarithmic function, logarithmic equations and inequalities, quadratic equations and functions, cosine theorem, Pythagorean theme, distance between two points, trigonometric equations, inequalities, inverse trigonometric functions, integrals and integrals. The topics of derivatives and differentials should be covered earlier in mathematics. The above mathematical knowledge makes it easy to master physics.

\section{REFERENCES}

1. N.Sh.Turdiev. VI -sinf Fizika darsligi. Toshkent 2006 yil. 18-b

2. P.Q.Habibullayev, A.Boydedayev,A.D.Bahromov,S.O.Burxonov. "Umumiy o'rta talim maktablarining 7-sinfi uchun fizika darsligi".2017 y.172-b

3. P.Q.Habibullayev,A.Boydedayev,A.D.Bahromov,M.K.Yuldasheva."Umumiy o'rta talim maktablarining 8-sinfi uchun fizika darsligi".2014 y.155-b

4. P.Q.Habibullayev, A.Boydedayev,A.D.Bahromov,M.K.Yuldasheva."Umumiy o'rta talim maktablarining 9-sinfi uchun fizika darsligi".2014 y.154-b

5. N.Sh.Turdiyev,K.A.Tursunmetov,A.G.G'aniyev,K.T.Suyarov,J.E.Usarov, A.K.Avliyoqulov "Umumiy o'rta ta'lim maktablarining 10-sinf uchun fizika darsligi”.2017 y.176-b

6. Sh.A.Alimov,O.R.Xolmuhamedov,M.A.Mirzaahmedov. "Umumiy o'rta ta'lim maktablarining 7-sinf uchun algebra darsligi"..2017 y.180-b

7. Sh.A.Alimov,O.R.Xolmuhamedov,M.A.Mirzaahmedov. "Umumiy o'rta ta'lim maktablarining 8-sinf uchun algebra darsligi".2014 y.220-b

8. Sh.A.Alimov,O.R.Xolmuhamedov,M.A.Mirzaahmedov. "Umumiy o'rta ta'lim maktablarining 9-sinf uchun algebra darsligi".2014 y.236-b

9. M.A.Mirzaahmedov,Sh.N.Ismailov, A.Q.Amanov "Umumiy o'rta ta'lim maktablarining 10-sinf uchun 1-qism algebra darsligi"..2017 y.86-b

10. B.Haydarov,E.Sariqov,A.Qo'chqorov. "Umumiy o'rta ta'lim maktablarining 9-sinf uchun geometriya darsligi".2014 y.154-b

11. M.A.Mirzaahmedov,Sh.N.Ismailov,A.Q.Amanov,B.Q.Haydarov "Umumiy o'rta ta'lim maktablarining 10-sinf uchun geometriya darsligi”.2017 y.143-b

12. Жўраев Р.Х, Умронхўжаев А Интегращия -янги сифат-Ж //Узлуксиз таълим 2002 №1 